\title{
Catalytic steam reforming of glycerol over cerium and palladium-based catalysts for hydrogen production
}

\begin{abstract}
In this work, catalytic steam reforming of glycerol for hydrogen production was performed over $\mathrm{Ce} / \mathrm{Al} 2 \mathrm{O} 3$ and $\mathrm{Pd} / \mathrm{Al} 2 \mathrm{O} 3$ catalysts prepared via the impregnation method. The catalysts were characterized by scanning electron microscopy (SEM-EDX), transmission electron microscopy (TEM), BET surface area, and X-ray diffraction (XRD). Two sets of catalytic reactions were conducted, one comparing $1 \% \mathrm{Pd} / \mathrm{Al} 2 \mathrm{O} 3$ to $1 \% \mathrm{Ce} / \mathrm{Al} 2 \mathrm{O} 3$ and the second comparing $1 \% \mathrm{Ce} / \mathrm{Al} 2 \mathrm{O} 3$ loading to $10 \% \mathrm{Ce} / \mathrm{Al} 2 \mathrm{O} 3$ loading. All catalytic reactions were performed using a fixed-bed reactor operated at $600{ }^{\circ} \mathrm{C}$ and atmospheric pressure. Aglycerolwater mixture at a molar ratio of 1:6 was fed to the reactor at $0.05 \mathrm{ml} / \mathrm{min}$. In the first set of experiments, $\mathrm{Pd} / \mathrm{A} 12 \mathrm{O} 3$ exhibited higher hydrogen productivity than $\mathrm{Ce} / \mathrm{Al} 2 \mathrm{O} 3$. A maximum hydrogen yield of $56 \%$ and a maximum selectivity of $78.7 \%$ were achieved over the $\mathrm{Pd} / \mathrm{Al} 2 \mathrm{O} 3$ catalyst. For the second set of experiments, the results show that the reaction conversion increased as the cerium loading increased from $1 \%$ to $10 \%$. A total average hydrogen yield of $28.0 \%$ and a selectivity of $45.5 \%$ were obtained over $1 \% \mathrm{Ce} / \mathrm{Al} 2 \mathrm{O} 3$, while the total average hydrogen yield and selectivity were $42.2 \%$ and $52.7 \%$, respectively, for $10 \%$ $\mathrm{Ce} / \mathrm{A} 12 \mathrm{O} 3$.
\end{abstract}

Keyword: Catalytic system; Glycerol; Hydrogen production; Reforming process. 